\section{RICHARD PIERRE CLAUDE}

Richard Pierre Claude epitomized the scholar/activist. As a student at Florida State in 1960, he sat down with friends at a lunch counter in Tallahassee in violation of municipal law. He had a distinguished career at the University of Maryland. One of his proudest achievements was the founding of the Human Rights Quarterly, which he edited for four years. The impetus for founding $H R Q$ was that the human rights field was dominated by lawyers, and while a number of social scientists were interested in doing scholarly work on human rights, the traditional journals were not receptive to this subject matter. Claude's vision for $H R Q$ may be evidenced by the results from Project Muse, an electronic website administered by Johns Hopkins University Press. Of the 436 journals on Project Muse, Human Rights Quarterly ranked third in terms of downloads of articles in 2010, with 207,440 .

Richard Claude coauthored with Burns Weston a leading coursebook in the human rights field, Human Rights in the World Community (University of Pennsylvania Press, 2006, $3^{\text {rd }}$ ed). An area to which he devoted substantial attention was science and human rights, working particularly closely with the Human Rights Program of the American Association for the Advancement of Science. Claude was a cofounder of Physicians for Human Rights. At Princeton, he taught a course on science and human rights and published an award winning book on the subject in the Pennsylvania Studies in Human Rights Series.

Richard was particularly proud of his work in human rights education. He presented workshops from Ethiopia to Burma and formulated a training manual used by the Inter-American Human Rights Institute, as well as a comparable "training for trainers" manual used in Asia from Indonesia to China. He passionately believed that education was the key to personal empowerment and essential to the enhancement of human dignity.

In recent years, he took up painting. Many scenes from his Georgetown neighborhood were featured, but true to Claude's heart, many of the works depicted articles from the Universal Declaration of Human Rights.

Richard Pierre Claude will be deeply missed by his colleagues in the human rights field.

Bert Lockwood University of Cincinnati and Urban Morgan Institute for Human Rights

\section{ROBERT LYNN SAVAGE}

Professor Emeritus Robert Lynn Savage, 71, of Fayetteville passed away January 26, 2011. He was born February 26, 1939, in Fort Worth, Texas. He served in the United States Air Force from 1956 to 1959. Savage received his BA degree from Tarleton State College in 1963 and his MA degree from the University of Houston, where he served as a graduate and teaching assistant from 1964 to 1966 . He graduated in 1966 with a thesis entitled "Absurdity and the Political System: The Political Thought of Albert Camus" under the direction of Professor John Green. Upon graduation, he served as an instructor before he continued his pursuit of a doctorate in political science from the University of Missouri-Columbia. He completed his academic work in 1971 with a dissertation entitled "Sociocultural Change and Policy Values in the American States." His dissertation chair was Professor Dan Nimmo, with whom Bob maintained a lifelong friendship. Nimmo's influence shaped Savage's interest in political communication and behavior and state politics. His first appointment as assistant professor brought him to Auburn University at Montgomery, where he worked from 1971 to 1974 , when he started his career at the University of Arkansas in the fall of 1974. He was promoted to associate professor just three years later in 1977 and to professor in 1982. He served as interim chair during that year and eventually as chair of the department from 1989 to 1998. Bob retired in 2001.

Bob Savage loved academia in its entire dimension. He taught both undergraduate and graduate classes in, among other areas, state and local government and politics, Southern politics, urban politics, and political communication, as well as classes or seminars on public opinion and political behavior. In addition, he taught a variety of methods courses and offered some classes for students pursuing their masters' degrees in public administration. $\mathrm{He}$ served as a mentor to many of us who joined the department when he was chair, and he left an indelible legacy on the department and its faculty.

Among his many publications were "Patterns of Multilinear Evolution in the American States" (Publius 3:75-108; reprinted in John Kincaid's 1982 volume Political Culture, Public Policy, and the American States); "Policy Innovativeness as a Trait of American States" (Journal of Politics 40:212-24); "Looking for Political Subcultures: A Critique of the Rummage-Sale Approach" (Western Political Quarterly 34:331-36); "Abortion Policies in the Fifty States: A Current Case of Pluralistic Responsiveness" (Southeastern Political Science Review Fall 1981, 34-55, with Diane Kincaid Blair); and "Dimensions of Responsiveness to Women's Policies in the American States" (Women and Politics 4:49-68, also with Diane Blair).

Besides his many contributions as the chair of the department, he never shunned serving the department, the college, and the university in other capacities that are too numerous to list here. He initiated the creation of the combined BA degree in political science and journalism, which exists to this day and has helped many journalism students interested in politics to deepen their understanding in their chosen field.

His love of state and local politics and policy was manifested in his many service contributions, which are too numerous to all name here. He was an active member in the Southwest Political Science and the Southwestern Social Science Associations and served as their president, as a member on the executive councils, and as panel chair and presenter for almost his entire academic career. Many of his colleagues remember him fondly as a participant in the annual meetings. He was a lifelong member of the American Political Science Association. He served on editorial boards, as well as an article reviewer for many academic journals.

Besides his academic work he enjoyed following politics, cooking, and the creative 